\title{
The Tree Biodiversity Network (BIOTREE-NET): prospects for biodiversity research and conservation in the Neotropics
}

\author{
Luis Cayuela, Lucía Gálvez-Bravo, Ramón Pérez Pérez, Fábio S. de Albuquerque, \\ Duncan J. Golicher, Rakan A. Zahawi, Neptalí Ramírez-Marcial, Cristina Garibaldi, \\ Richard Field, José M. Rey Benayas, Mario González-Espinosa, Patricia Balvanera, \\ Miguel Ángel Castillo, Blanca L. Figueroa-Rangel, Daniel M. Griffith, Gerald A. Islebe, \\ Daniel L. Kelly, Miguel Olvera-Vargas, Stefan A. Schnitzer, Eduardo Velázquez, \\ Guadalupe Williams-Linera, Steven W. Brewer, Angélica Camacho-Cruz, Indiana \\ Coronado, Ben de Jong, Rafael del Castillo, Íñigo Granzow-de la Cerda, Javier \\ Fernández, William Fonseca, Luis Galindo-Jaimes, Thomas W. Gillespie, Benigno \\ González-Rivas, James E. Gordon, Johanna Hurtado, José Linares, Susan G. Letcher, \\ Scott A. Mangan, Jorge A. Meave, Ernesto V. Méndez, Victor Meza, Susana Ochoa- \\ Gaona, Chris J. Peterson, Viviana Ruiz-Gutierrez, Kymberley A. Snarr, Fernando Tun \\ Dzul, Mirna Valdez-Hernández, Karin M. Viergever, David A. White, John N. Williams, \\ Francisco J. Bonet \& Regino Zamora
}

\begin{abstract}
Biodiversity research and conservation efforts in the tropics are hindered by the lack of knowledge of the assemblages found there, with many species undescribed or poorly known. Our initiative, the Tree Biodiversity Network (BIOTREE-NET), aims to address this problem by assembling georeferenced data from a wide range of sources, making these data easily accessible and easily queried, and promoting data sharing. The database (GIVD ID NA-00-002) currently comprises ca. 50,000 tree records of ca. 5,000 species ( 230 in the IUCN Red List) from >2,000 forest plots in 11 countries. The focus is on trees because of their pivotal role in tropical forest ecosystems (which contain most of the world's biodiversity) in terms of ecosystem function, carbon storage and effects on other species. BIOTREE-NET currently focuses on southern Mexico and Central America, but we aim to expand coverage to other parts of tropical America. The database is relational, comprising 12 linked data tables. We summarise its structure and contents. Key tables contain data on forest plots (including size, location and date(s) sampled), individual trees (including diameter, when available, and both recorded and standardised species name), species (including biological traits of each species) and the researchers who collected the data. Many types of queries are facilitated and species distribution modelling is enabled. Examining the data in BIOTREE-NET to date, we found an uneven distribution of data in space and across biomes, reflecting the general state of knowledge of the tropics. More than $90 \%$ of the data were collected since 1990 and plot size varies widely, but with most less than one hectare in size. A wide range of minimum sizes is used to define a 'tree'. The database helps to identify gaps that need filling by further data collection and collation. The data can be publicly accessed through a web application at http://portal.biotreenet.com. Researchers are invited and encouraged to contribute data to BIOTREE-NET.
\end{abstract}

Keywords: Central America; data linking; data sharing; relational database; southern Mexico; species distribution modelling; tropical forest.

Received: 12 January 2011 - Accepted: 30 September 2011 - Co-ordinating Editor: Gabriela Lopez-Gonzalez.

\section{Introduction}

One of the main problems in conservation biology is a shortage of data on organisms (Myers et al. 2000, Brooks et al. 2001,
Olson \& Dinerstein 2002, Funk et al. 2005). Many species are not yet formally named and catalogued (the 'Linnaean shortfall', Brown \& Lomolino 1998), and a large proportion of those that have been taxonomically described lack adequate data on their global, regional or even local distribution (the 'Wallacean shortfall', Lomolino 2004). Not surprisingly, collection and monitoring efforts in some parts 
of the world have been insufficient to produce reliable, systematic range maps across much of the earth's surface - even for the relatively heavily studied higher plants (Whittaker et al. 2005). The Convention for Biological Diversity (United
Nations 1992) aimed "to achieve by 2010 a significant reduction in biodiversity loss at the global, regional and national levels". However, these goals have not been met and extinction rates are likely to increase further in the future (Pereira et al.
2010). Reversing these trends requires, among other things, effective monitoring schemes, yet we currently lack the comprehensive data needed (Pereira \& Cooper 2006).

\section{GIVD Database ID: NA-00-002}

\section{Tree Biodiversity Network (BIOTREE-NET)}

Scope: BIOTREE-NET is a network of forest inventory plots in southern Mexico and Central America. Its major goal is to promote biodiversity research and conservation in the tropics by stimulating data sharing and collaboration between scientists from different parts of the world.

Status: completed and continuing Period: 1969-2009

Database manager(s): Luis Cayuela (luis.cayuela@urjc.es)

Owner: Public

Web address: http://portal.biotreenet.com/

Availability: free online

Online upload: no

Online search: yes

Database format(s): PostgreSQL

Export format(s): SQL, CSV file, plain text file

Publication: Since BIOTREE-NET pools together several datasets, there are publications describing the data for most of the individual datasets (see list of primary sources), but there is not yet any publication describing all the data within BIOTREE-NET as a whole.

Plot type(s): normal plots

Non-overlapping plots: 2,019

Plot-size range: $100-54000 \mathrm{~m}^{2}$

Total plot observations: 2,019

Estimate of existing plots: [NA]

Number of sources: 53

Completeness: [NA]

Valid taxa: 1,188

Countries: BZ: 1.6\%; CR: 10.2\%; HN: 6.9\%; MX: 65.9\%; NI: 2.1\%; PA: $9.9 \%$; SV: $3.4 \%$

Forest: $100 \%$ - Non-forest: aquatic: $0 \%$; semi-aquatic: $0 \%$; arctic-alpine: $0 \%$; natural: $0 \%$; semi-natural: $0 \%$; anthropogenic: $0 \%$

Guilds: only trees and shrubs: $100 \%$

Environmental data: [NA]

Performance measure(s): presence/absence only: $10 \%$; number of individuals: $90 \%$; measurements like diameter or height of trees: $21 \%$

Geographic localisation: GPS coordinates (precision $25 \mathrm{~m}$ or less): $75 \%$; point coordinates less precise than GPS, up to $1 \mathrm{~km}$ : $20 \%$; small grid (not coarser than $10 \mathrm{~km}$ ): $5 \%$

Sampling periods: $1960-1969$ : 0.0\%; 1980-1989: 0.4\%; 1990-1999: 33.0\%; 2000-2009: 59.9\%; unknown: 6.9\% Information as of 2012-07-19; further details and future updates available from http://www.givd.info/ID/NA-00-002

Data shortfalls are especially characteristic of tropical areas (Bawa et al. 2004), where most of the world's megadiverse areas occur (Myers et al. 2000, Funk and $\mathrm{Fa} 2010$ ), and where rates of habitat loss and environmental degradation are highest (Laurance 1999, Brooks et al. 2002, Sodhi et al. 2004, Wright \& MullerLandau 2006, Hoffmann et al. 2010). Species loss in the tropics is difficult to quantify (Laurance 2007, Stork 2010), but at least half of the species in these areas are threatened with extinction (Bradshaw et al. 2009). Reducing the further loss of irreplaceable tropical biodiversity has never been more compelling. Accordingly, there is an urgent need, particularly in these regions, to assemble and share information on biodiversity, increase collaborations between tropical biologists and stakeholders, and develop research tools to assist conservation planning, policy development and implementation (Bawa et al. 2004, Boreux et al. 2009, Shanley \& Lopez 2009).

Recently several initiatives have tried to address these information gaps at supra-national or global scales. One such initiative, the Global Biodiversity Infor- mation Facility (GBIF, http://www. gbif.org), has collated millions of data entries from natural history collections, library materials, and databases (Yesson et al. 2007). However, a large proportion of the information currently available in GBIF refers to developed countries, whereas huge information gaps remain in many developing countries, particularly those in the tropics (Cayuela et al. 2009). Therefore, more work is needed to identify and fill these gaps. The effectiveness and utility of global initiatives is enhanced when complementary networks work, at smaller scales, to improve the structure and content of datasets that focus on specific regions or taxa. One of the best regional examples of this is the Biodiversity and Environmental Resource Database System (BERDS) of Belize (http://www.biodiversity.bz/), which uses a spatially explicit, relational database for data storage, display, and analysis. Other examples that demonstrate effective collaboration and data sharing are the RAINFOR initiative (Malhi et al. 2002), and the Amazon Plot Network (Ter Steege et al. 2006). Data from these smaller but more specific and thus more manageable databases can be integrated into larger exchange programmes, such as the ForestPlots.net database (LopezGonzalez et al. 2012) or the Group on Earth Observations - Biodiversity Observation Network (GEO BON, Scholes et al. 2009, http://www.earthobservations. com/geobon.shtml).

It is in this context that the Tree Biodiversity Network (BIOTREE-NET) emerged as an international initiative whose objective is to organise and store tree data from forest inventory plots in a structured and standardised manner, including spatial information. BIOTREE-NET was developed to contain information on trees (and eventually lianas) from a wide range of tropical forests, including primary and secondary forests, across southern Mexico and Central America. Soon the geographical scope will be expanded to include tropical countries from northern South America, to cover the full distributional range of most neotropical species. The ultimate goal of the BIOTREE-NET project is to provide researchers, managers, and conservation practitioners access to biodiversity data from one of the most diverse and under-explored regions of the 
world. The specific aims of the project are to: (1) collate existing information on tree biodiversity data and make them accessible to the wider scientific community; (2) integrate, standardise and organise forest plot data, providing relevant meta-data; (3) provide users with data analysis and modelling tools, including species distribution modelling functionality; (4) link spatial tree data with the latest information on species' biological traits; (5) promote data sharing among the scientific community; (6) identify information gaps and formulate research proposals to ad- dress those gaps; and (7) contribute to global programmes of biodiversity data sharing with well-structured, comprehensive data. The purpose of this paper is to review the scope, data, and key features of the BIOTREE-NET database.
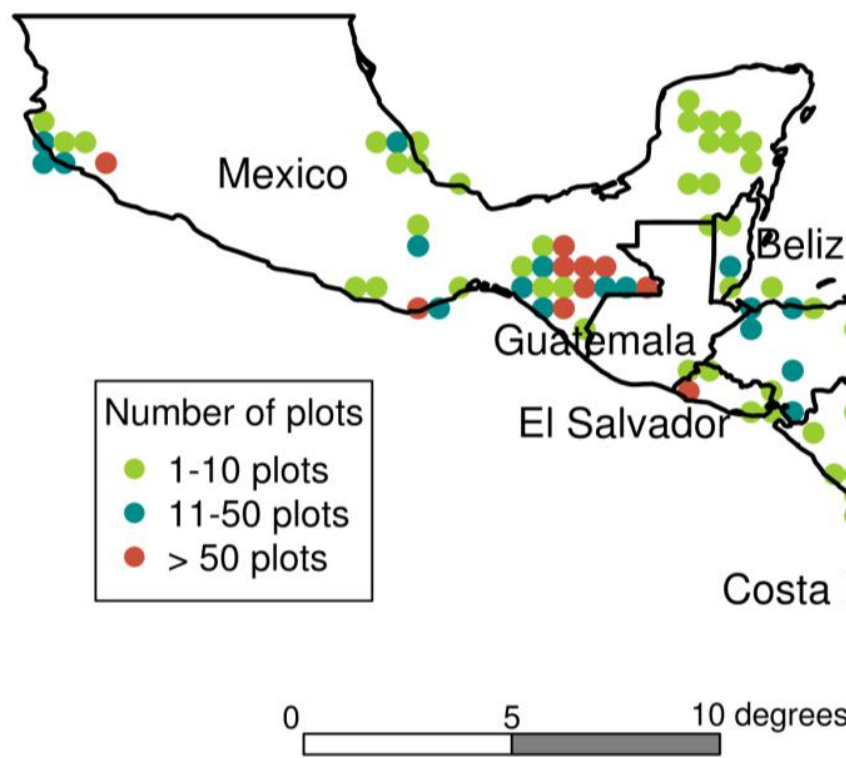

Fig. 1: Distribution of forest plots, aggregated in $0.5 \times 0.5$ degree cells, across Central America and southern Mexico (including the states of Colima, Jalisco, Quintana Roo, Yucatan, Campeche, Tabasco, Veracruz, Chiapas, Oaxaca, Guerrero, and Michoacan).

\section{Scope}

BIOTREE-NET contains tree abundance or presence-absence data from plots located in tropical forests of southern Mexico and Central America (Fig. 1). This region requires urgent biodiversity research and conservation initiatives. Despite containing an estimated $7 \%$ of global biodiversity on less than $1 \%$ of the world's land surface (Myers et al. 2000), this region experiences rates of deforestation and environmental degradation that are among the highest in the world (DeClerck et al. 2010, Hoffmann et al. 2010). Yet there are insufficient human and financial resources to explore even the most basic ecological aspects of most of the species that occur in the region (Cayuela et al. 2009).

BIOTREE-NET focuses mostly on trees, instead of other taxa, for several reasons. First, trees are important globally, as species of conservation interest in themselves, especially in the tropics. Second, trees provide habitat, refuge and food for many other species (e.g. insects, Novotny et al. 2006), and provide structural support for other life-forms, such as epiphytes (Sporn et al. 2010), lianas (Dewalt et al. 2000) and fungi (Zhao et al. 2003). Consequently, understanding tree diversity is crucial to understanding the overall biodiversity of tropical forests (e.g. Erwin 1982, Kissling et al. 2010) Third, trees control erosion and help regulate the local climate, mitigating largescale environmental problems such as pollution and climate change (Bonan 2008, Ponette-Gonzalez et al. 2010). Fourth, as sessile, conspicuous organisms, trees are relatively easy to study compared to more elusive organisms (Lughadha et al. 2005). Finally, trees account for the majority of the biomass in terrestrial ecosystems (Lughadha et al. 2005). As a result, there is generally a larger amount of information available about trees in tropical regions, compared with other plant groups such as herbs or fungi. Focusing on trees therefore provides a useful, attainable starting point for comprehensive data compilation.

At present, over 40 independent researchers from 11 countries have contributed to the BIOTREE-NET initiative (see Acknowledgements). Data from forest inventory plots contained in this database vary in their nature (abundance, presenceabsence), shape and extent of sampling area, minimum diameter at breast height (dbh) at which trees are recorded, and data quality. Some inventory plots have been resampled throughout time, and others have not.

\section{Database structure and data storage}

BIOTREE-NET is based on a relational database that includes 12 tables (Fig. 2). 
The tables store information about each individual plot, the botanical name of each individual tree, diameter measurements, and biological traits of the species. Not all of these data are available for all individual plots.

Given that the data amassed into BIOTREE-NET are forest plot data, we start our description of the database structure with the table inventory. This contains plot information, including location, sampling area and sampling protocol. It is linked to the table projects, which refer to groups of forest plots that have been surveyed largely by the same researcher(s) within a certain time-period; in turn, this table links to one called institution, giving more information about those projects. The table inventory also links to one called people (name and contact details of the researcher(s) responsible for each forest plot), via the intermediary inventory_people. The table inventory also links to temporal, which contains information about the date of sampling and minimum dbh criterion; if a forest plot has been sampled $\mathrm{n}$ times, there are $\mathrm{n}$ entries with the same inventory id in this table.

Information at the individual tree level is stored in an observation table, where each species is assigned a unique identifier (Fig. 2). Contrary to other biodiversity databases, a typical entry in the BIOTREE-NET database does not correspond to an individual tree, but to an identified species, for which there is either information on the number of individuals that were recorded in a forest plot (i.e. abundance data) or a record indicating that the species was present in that plot (i.e. presence-absence data). This approach allows us to more easily focus on species-specific patterns within and across plots. The name of the person(s) that carried out the taxonomic identification of each species is also included in this table. If information about diameter measurements is available, it is stored in the table observation_dbh. This table includes the dbh measurement of individual trees, so the unique identifier for each species (from table observation) appears in the table observation_dbh as many times as individuals of this species with dbh information have been registered. The table observation is also linked (via the intermediary inventory_people) to the table taxon, which holds taxonomic information about tree species after standardising species names and correcting misspellings and typographical errors (see below). Fi- nally, the table ecoprofiles stores data on the biological traits and taxonomic description of species that are stored in the table taxon, e.g. habit, scientific description, habitat, endemism, mean plant height, fire tolerance, stem density, mean seed length, leaf size, deciduousness and dispersal syndrome. Information on ecoprofiles is being compiled by a team of expert botanists and ecologists from different countries and it is therefore generated independently from the plot data. These data are linked to each species in the table taxon to provide relevant ecological information, and to increase the usefulness of the database by identifying all registered species that have a particular trait, such as a particular dispersal syndrome, through just one search query. Images of the ecoprofiles are contained in the final table, imagesecoprofiles. Moredetailed information on the BIOTREENET relational database can be found in Cayuela et al. (2010).

\section{Taxonomic standardisation}

Data by themselves are not sufficient for competent, high-level research and management recommendations. Given the considerable taxonomic variability arising from the use of different systems and the rapid changes in nomenclature, it is necessary to standardise this information and correct spelling mistakes and typographical errors as much as possible, in order to make reliable inferences. Acquisition of pertinent information, processing, quality control, archiving, timely access and database management are important components that will make the information valuable and usable in research and operational programs (Doraiswamy et al. 2000).

In BIOTREE-NET we used the Plant List (http://www.theplantlist.org/) to accomplish this task. The Plant List is a working list of all known plant species, which provides the accepted Latin name for most species, with links to all known synonyms for that species. It also includes unresolved names for which the contributing data sources did not contain sufficient evidence to decide whether they are accepted or synonyms.

We wrote an automated procedure in the $\mathrm{R}$ environment (Cayuela 2012) to cross-check all species names in our database against the Plant List database (Fig. 3). If the species name was contained in the Plant List, then we extracted information on whether the species name was accepted, a synonym or unresolved. In case the species was a synonym, the validated name was also obtained from the Plant List.

For the species that were not found in the Plant List, we searched for approximate matches to all species within the genus, provided that this information was available and correctly written, using the Approximate String Matching (agrep) function in $\mathrm{R}$ ( $\mathrm{R}$ Development Core Team 2011). This enables automatic identification and correction of typographical errors. For the remaining species, we conducted a non-automated revision of species names to identify: (1) further typographical errors not detected automatically in the previous step; (2) morphospecies, i.e. species identified to genus or family level based on morphological traits; and (3) existing species names which are not currently included in the Plant List. In the case of morphospecies we reassigned the species and gave it a unique name for further analyses. For instance, consider that researcher A and researcher B have identified a species based on morphological traits and labelled it as Persea sp1. These two identifications can refer to different species because researcher A and B have not cross-checked their identifications. Therefore, in order to avoid commission errors, the name of the project is added to the species name in table 'taxon', e.g. Persea sp1_CBR vs Persea sp1_TZA. In case a species name is not included in the Plant List, other taxonomic checklists will be examined (Fig. 3), such as the Chicago Botanical Garden or the New York Botanical Garden databases.

\section{Technical specification}

The BIOTREE-NET project aims to address the needs of researchers and end users. Therefore, we designed a system that is accessible from the Internet (http://portal.biotreenet.com), which provides a web interface and a set of web services that allow both human-machine and machine-machine interactions. The system development has followed a threelayer architecture that is widely used in software development: model, view and controller (Leff \& Rayfield 2001). This architecture allows the management of different layers independently so that changes in one layer do not affect other layers. 


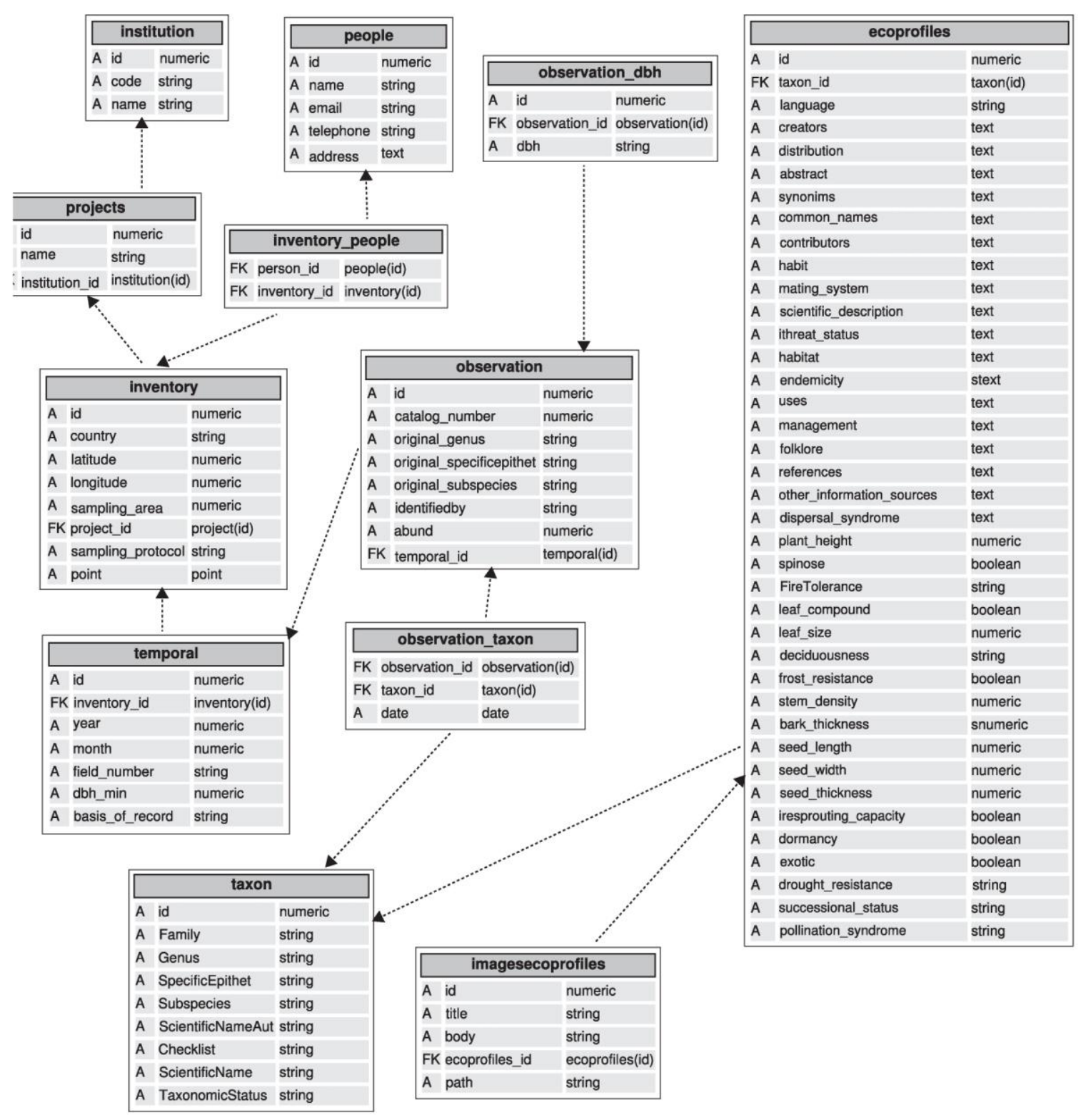

Fig. 2: The BIOTREE-NET data tables and their inter-relationships. Dotted lines show how tables are linked, with arrows indicating directionality of subordination between tables. Some tables are designed only to link the main data tables together (see text). The main data tables all contain identifier fields labelled 'id'. In the table inventory this identifies the forest plot; in temporal it identifies the sample/census; in observation it refers to the recorded (raw) species identification, while in taxon it refers to the corrected species identification; in observation_dbh it identifies the dbh measurement; in ecoprofiles it identifies the trait and in imagesecoprofiles it refers to an image of that trait. These and other fields are marked as attributes with an ' $A$ ', except for fields in subordinate tables that link to the 'master' table (the dotted lines); these fields are labelled 'FK'.

The framework used for the development of the system is Ruby on Rails (RoR, Ruby et al. 2009). RoR enables agile software development by abstracting the functionality of the model, view and controller layers. The differentiation into layers allows for greater control and security as well as the implementation of, independent modules that complement the functionality of the project. Advantages to this framework include authentication multi-language, security layer, abstract model layer, large development community and open source.

The model layer is implemented in PostgreSQL and PostGIS (Fig. 4) to cover alphanumeric and spatial data. In reference to forest plots, spatial data are repre- sented by a point vector layer indicating the plot centroid. In addition, a set of auxiliary layers are also managed from PostGIS, including administrative boundaries (countries, states, counties), forest types (Arino et al. 2008), ecoregions (WWF 2010), and natural protected areas (WDPA 2010). Raster layers, including climatic and topographical data (Hijmans 


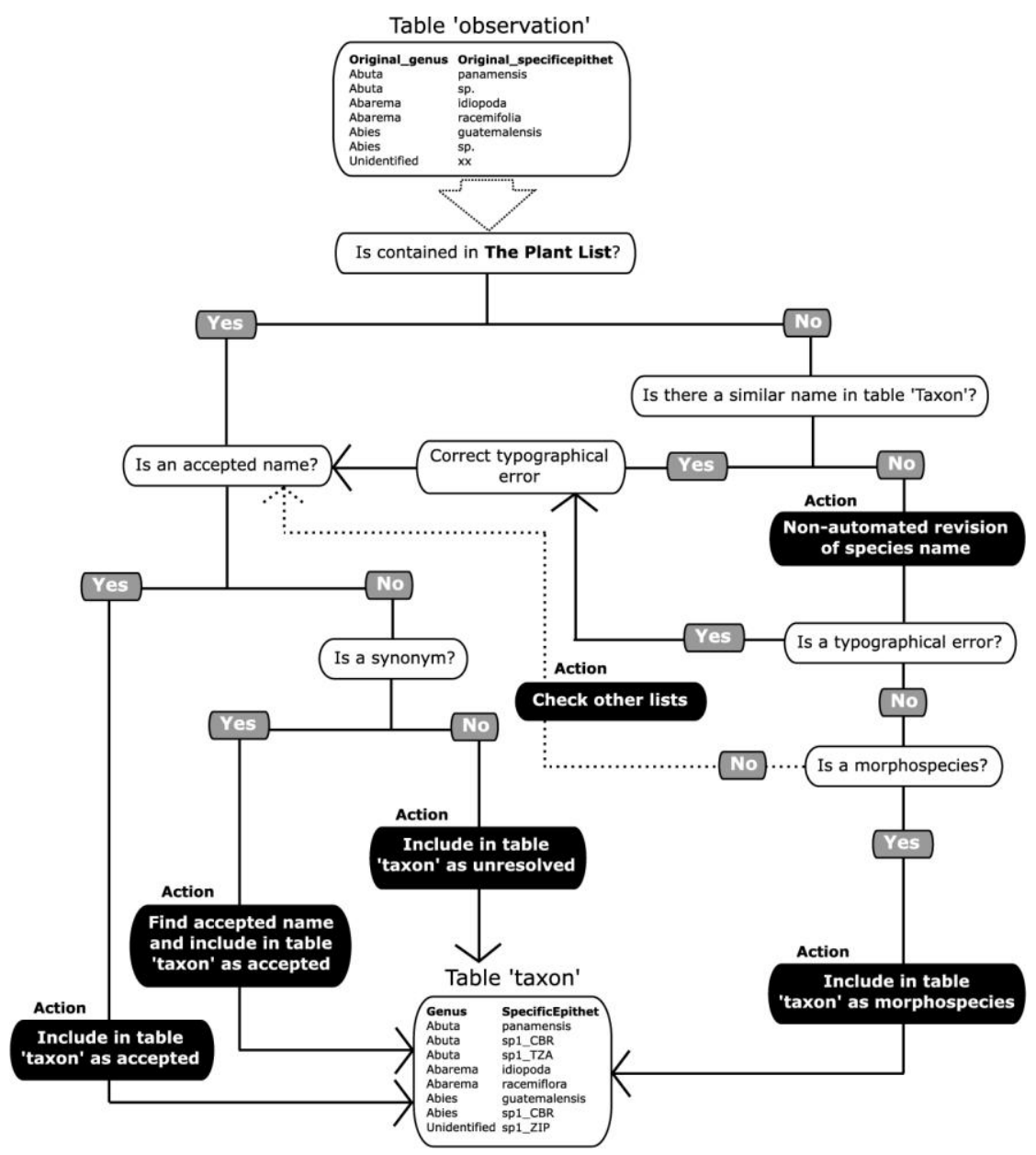

Fig. 3: Protocol for taxonomic standardisation of species names in BIOTREE-NET.

et al. 2005), will be also included within a global spatial data infrastructure. Spatial vector and raster layers cannot be made publicly available within BIOTREE-NET because intellectual property rights are protected in most cases, but project participants will be given privileged access.

The view layer (front-web and web in services) provides an interface for the user or machine with the BIOTREE-NET project (Fig. 4). This layer is implemented in Dynamic HTML, CSS and Javascript for the front-web, and SOAP for Web Services. The controller layer manages requests through the view layer, performs the required actions, and when necessary, provides access to the model layer. The controller layer is mainly managed in Ruby (Fig. 4). Other technologies (such as from Mexico (65.9\%), followed by Costa Rica (10.2\%), Panama (9.9\%), Honduras (6.9\%), El Salvador (3.4\%), Belize (2.1\%) and Nicaragua (1.6\%) (Fig. 5a). Figures change slightly if we look at the total sampled area by country, with Mexico holding the largest total sampled area (135.89 ha), followed by Panama (114.16 ha), Costa Rica (29.43 ha), Honduras (12.29 ha), El Salvador (6.39 ha), Nicaragua (6.15 ha) and Belize (5.33 ha). No data have yet been collated from Guatemala but some forest plots have already been identified and new research projects are to be launched in this country in the near future. Forest plots and total sampled area are also unevenly distributed across ecoregions (Table 1); this probably represents a general pattern in forest data. Five out of the 42 ecoregions present in this area account for $64.6 \%$ of all forest plots, and 14 ecoregions have no information (listed in Table 1 legend). This disparity in plot distribution is due mainly to the specific interests of researchers and access to large datasets of particular regions, such as the Central American pine-oak forests ecoregion (Plate A), the PetenVeracruz moist forests, or the IsthmianAtlantic and Isthmian-Pacific moist forests (Plate B). Even within these large ecoregions, forest plots are unevenly distributed. For example, in Central American pine-oak forests, more than $90 \%$ of the plots are concentrated in southern Mexico, while (as previously indicated), no plots are available for Guatemala, and only a few plots are located in Honduras and El Salvador. Around $68 \%$ of all the forest plots are outside protected areas. Some protected areas are, however, relatively well sampled, such as El Triunfo (92 plots), and Sierra de Manantlán Biosphere Reserve (87 plots), in Mexico. The vast majority of forest plots (ca. 98\%) in the BIOTREE-NET database have been censused only once. Most forest plots were sampled between 2001 and 2010 (59.9\%) and 1991-2000 (39.0\%) (Fig. $5 b)$. Only a few plots from Palo Verde National Park in Costa Rica (0.39\%; Hartshorn 1983) and north central Yucatan in Mexico $(0.05 \%$; White and Hood 2004) were sampled prior to 1990. 


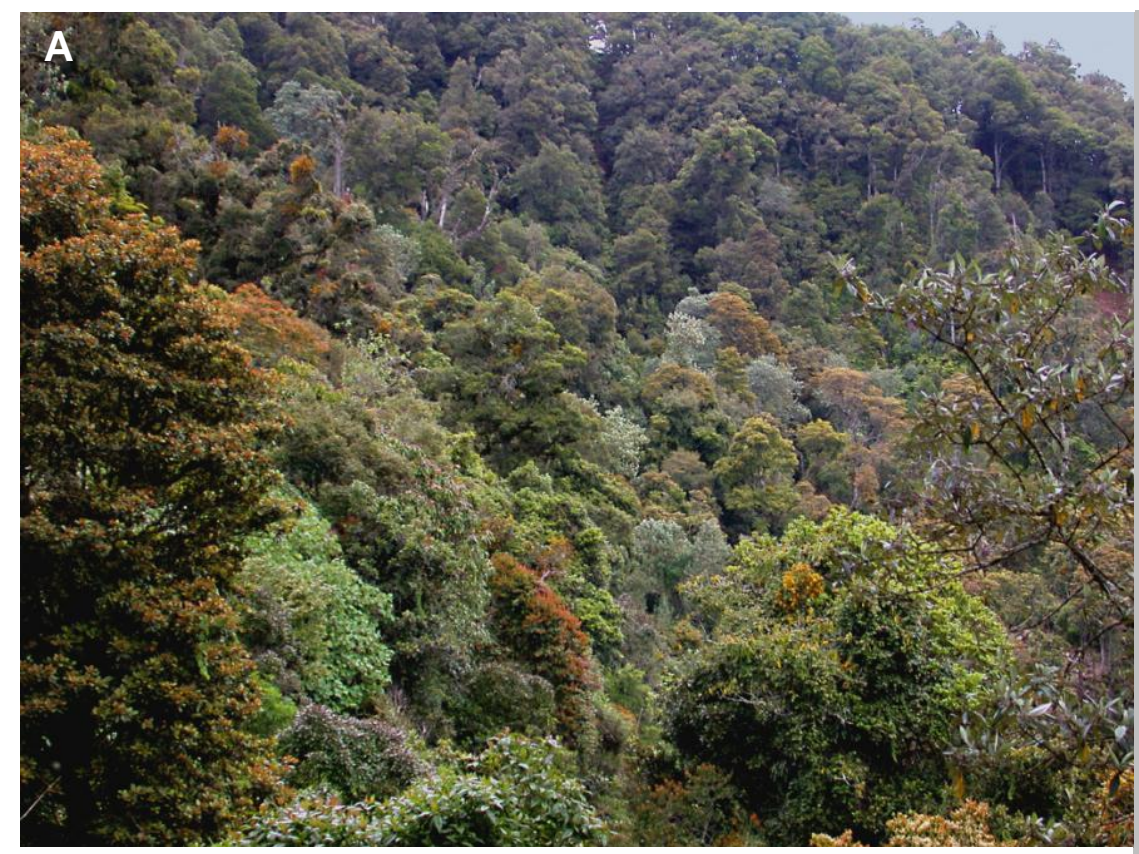

Plate: Some of the most common vegetation types featured by the BIOTREENET database (GIVD ID NA-00-002).

A: Central American pine-oak forest in the Huitepec Reserve, southern Mexico (Photo: N. Ramírez-Marcial).

B: Isthmian-Pacific moist forest in Cerro La Tronosa, Panama (Photo: C. Garibaldi).

C: Chiapas Depression dry forest in Jiquipilas, southern Mexico (Photo: N. Ramírez-Marcial).
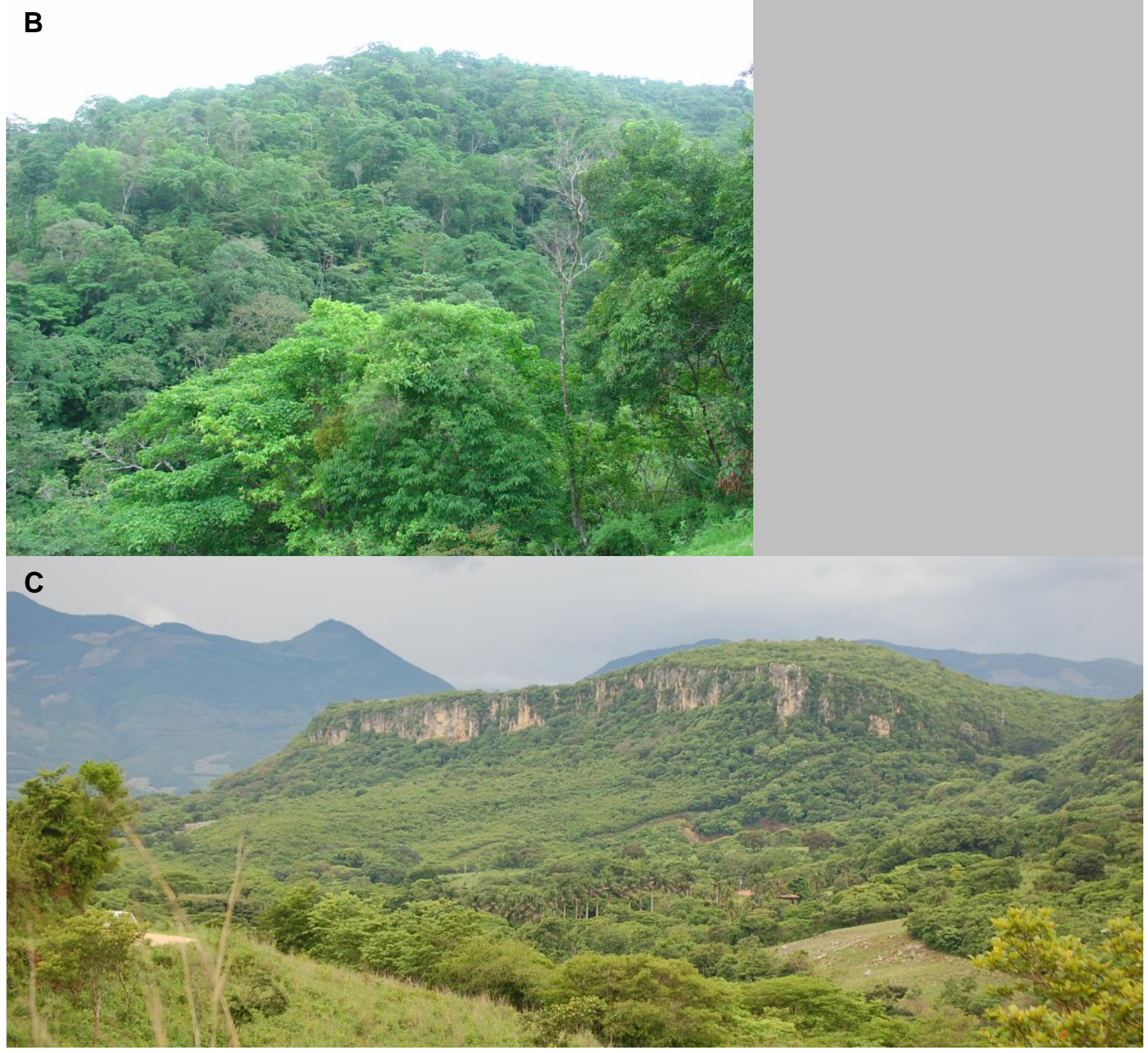


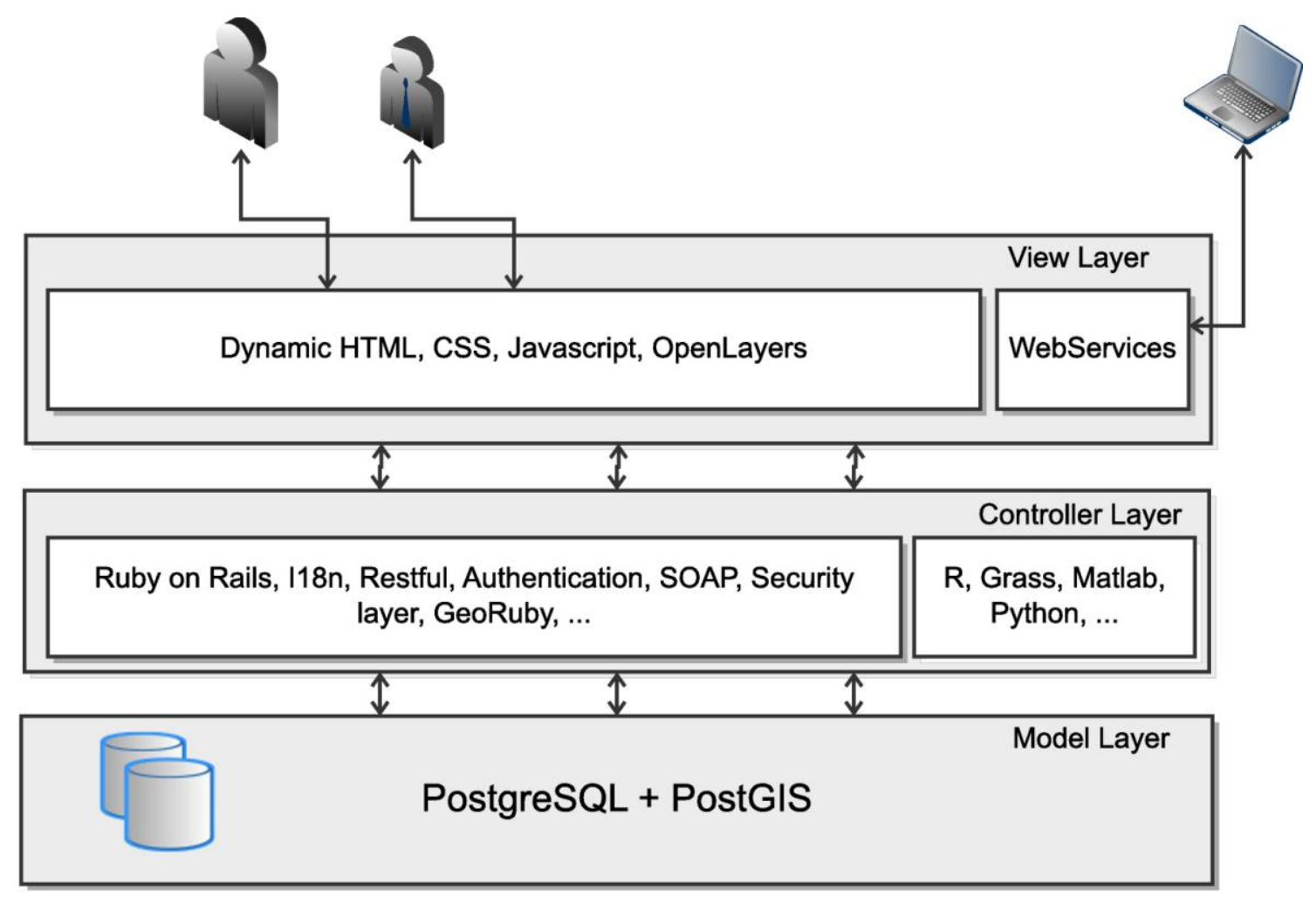

Fig. 4: Technical specification of the BIOTREE-NET project and global view of the system, including the model, view and controller layers.

Nearly $7 \%$ of forest plots were undated. Sampling protocols and the type of data collected vary considerably within the BIOTREE-NET forest inventory plots. Most of the forest plots contain data on tree species abundance $(90.4 \%)$, the rest being presence-absence data only. In the plots with abundance data, $73.5 \%$ contain fewer than 100 stems, followed by plots with 100-500 stems (23.6\%), plots with $500-1,000$ stems $(1.7 \%)$, and plots with $1,000-5,000$ stems $(1.2 \%)$. Around $20 \%$ of the forest plots have information on tree diameter. Plot shape also varies considerably, and sampling protocols include circular plots, quadrats, nested plots, transects and rapid biodiversity surveys. There is also a wide variation in sampling area (Fig. 5c). A large proportion of forest plots are small, with sampled areas of $0.05-0.1$ ha $(48.0 \%)$ or $0.01-0.05$ ha $(34.4 \%)$. Larger plots are less common, with $1.9 \%$ in the range $0.1-0.2$ ha, $5.1 \%$ $0.2-0.5$ ha, $7.5 \% \quad 0.5-1$ ha and only $0.2 \%$ of the plots being larger than 1 ha. The largest sampled areas often correspond to a set of smaller sub-samples for which detailed tree species data have been pooled. In such cases, geographical coordinates often indicate the centroid of all sub-samples. More detailed information from these forest plots may be available in a near future. The minimum dbh at which individual trees were recorded for most of the plots was $5 \mathrm{~cm}(47.1 \%)$ or 10 $\mathrm{cm}$ (29.8\%); however, some plots included smaller trees (Fig. 5d).

Of the forest plots, $68.8 \%$ were obtained from published scientific papers. Of these, only $6 \%$ were available for

a)

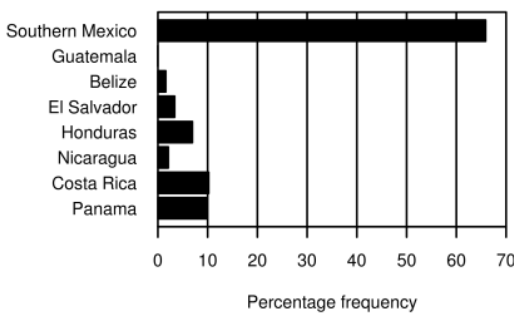

c)

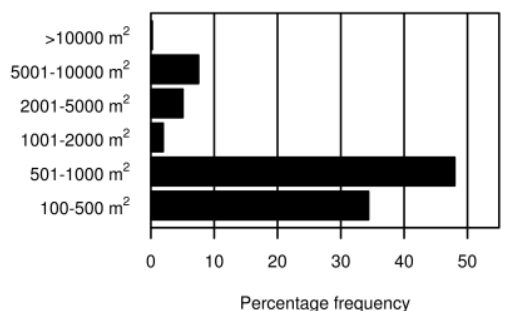

download via the Internet. Around 14.6\% were unpublished forest plot data from degree and master theses or technical reports. Finally, ca. 17\% of all forest plots come from unpublished surveys carried out by researchers and conservation organisations.

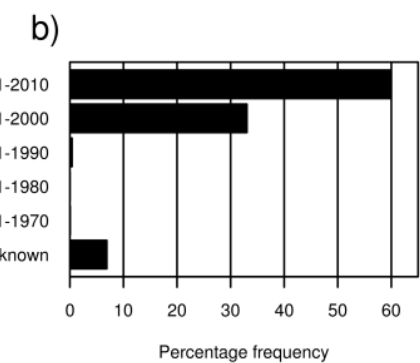

d)

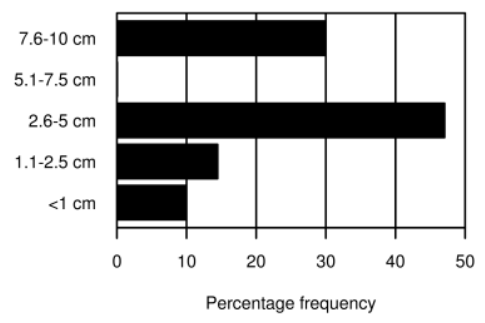

Fig. 5: Percent frequency of forest plots included in the BIOTREE-NET database according to: (a) country; (b) decade (1961 to 2010); (c) individual plot size; and (d) minimum dbh of trees measured. 
Table 1: Ecoregions (WWF 2010) for which there are forest inventory plots in the BIOTREE-NET database and total sampled area (ha). Ecoregions are defined as large areas of land or water that contain a geographically distinct assemblage of natural communities that: (a) share a large majority of their species and ecological dynamics; (b) share similar environmental conditions, and; (c) interact ecologically in ways that are critical for their long-term persistence (Dinerstein et al. 2000). There is no information available for the following 14 ecoregions: Bajo dry forests, Balsas dry forests, Chimalapas montane forests, Choco-Darien moist forests, Motagua valley thornscrub, Northern Mesoamerican Pacific mangroves, Panamian dry forests, Pantanos de Centla, Sierra Madre Occidental pine-oak forests, Sierra Madre Oriental pine-oak forests, Sinaloan dry forests, South American Pacific mangroves, Tehuacan valley matorral, Veracruz montane forests. Eighteen plots need revised geographical coordinates and, consequently, could not be assigned yet to a specific ecoregion.

\begin{tabular}{lcc}
\hline \multicolumn{1}{c}{ Ecoregion } & Number of plots & Total sampled area (ha) \\
\hline Central American pine-oak forests & 709 & 69.80 \\
Isthmian-Atlantic moist forests & 199 & 114.91 \\
Peten-Veracruz moist forests & 154 & 12.50 \\
Chiapas montane forests & 125 & 13.74 \\
Isthmian-Pacific moist forests & 119 & 10.71 \\
Sierra Madre de Chiapas moist forests & 95 & 9.60 \\
Trans-Mexican Volcanic Belt pine-oak forests & 88 & 4.42 \\
Southern Pacific dry forests & 85 & 12.25 \\
Central American Atlantic moist forests & 80 & 3.87 \\
Talamancan montane forests & 70 & 9.37 \\
Chiapas Depression dry forests & 53 & 5.20 \\
Jalisco dry forests & 51 & 7.11 \\
Central American montane forests & 32 & 3.10 \\
Oaxacan montane forests & 30 & 2.88 \\
Central American dry forests & 27 & 11.42 \\
Yucatan moist forests & 26 & 3.93 \\
Mesoamerican Gulf-Caribbean mangroves & 14 & 0.77 \\
Costa Rican seasonal moist forests & 12 & 2.20 \\
Veracruz dry forests & 10 & 1.00 \\
Yucatan dry forests & 6 & 1.86 \\
Southern Mesoamerican Pacific mangroves & 5 & 0.75 \\
Belizian pine forests & 3 & 2.43 \\
Veracruz moist forests & 2 & 0.20 \\
Sierra Madre del Sur pine-oak forests & 2 & 0.25 \\
Eastern Panamanian montane forests & 1 & 1.00 \\
Miskito pine forests & 1 & 0.15 \\
Sierra de los Tuxtlas & 1 & 0.10 \\
Sierra Madre de Oaxaca pine-oak forests & 1 & 1.00 \\
\hline Total & & 306.52 \\
\hline
\end{tabular}

The BIOTREE-NET database is a valuable source of floristic information. There are more than 5,000 species names in the database, although a large proportion (20$30 \%$ ) corresponds to morphospecies. A list of the 20 most frequent species in the database is presented in Table 2, which mostly correspond to montane pine-oak forest species. In total there are 49,982 observations (each observation refers to an identified species within a forest plot, for which there is associated information on either abundance or presence). Two hundred and thirty of the tree species are included in the IUCN Red List of Threatened Species (IUCN 2010) under the categories of extinct in the wild (1), critically endangered (9), endangered (50), vulnerable (87), near threatened (2), low risk (73), least concern (3), and data deficient (5).

\section{Future outlook}

We are now working on an improved structure for the BIOTREE-NET database, developing web applications and data analysis tools. Data quality control is an important issue that needs on-going work and periodical evaluation. Some taxonomic errors can be identified by means of potential species distribution models. The accuracy of geographical coordinates also needs to be assessed. Geographical misallocations of a few dozens of meters can be irrelevant for macroecological analyses, but larger errors can have important consequences for data analyses, particularly in the context of species distribution modelling (Guisan et al. 2007). Information about biological and ecological attributes of species is currently being generated. This information is already available for ca. 300 species (N. Ramírez-Marcial, unpublished data), but the target is to reach 1,000 species by the end of the project and to enable an editing system to allow researchers to continue generating and editing this information in the future. This will be especially relevant for species conservation, for example, through the design of restoration protocols that consider seed dispersal mechanisms, and shade or drought tolerance of seedlings.

We strongly believe that a free, readily available and comprehensive database such as BIOTREE-NET may encourage 
more proactive conservation measures in those countries where scientific effort (e.g. inventories) is limited by economic and accessibility constraints. As more data become part of the network, it will allow for the identification of knowledge gaps with respect to specific geographical areas and/or tree families and species, and this in turn will help focus resources to maximise the usefulness of results. It will also help identify new sources of information, and promote interactions between researchers and research institutions from different areas through common research and technical activities. Through BIOTREE-NET, scientists working in Central America and southern Mexico will be able to identify and contact other researchers working towards common goals and/or in similar areas, and we hope this will promote collaborations and further exchanges of data and ideas. Although governmental and non-governmental conservation agencies fund academic research, they often do not use the results of such research to guide conservation policies in practice (Prendergast et al. 1999). Since BIOTREE-NET aims to include data from all suitable sources, we will try to involve as many regional/national government bodies as possible, so that data that may be obscured in official reports become readily available to researchers. Additionally, it may help politicians and wildlife managers establish collaborations with other regions or countries when planning species-specific conservation plans.

As an open-access database, BIOTREE-NET can be extremely useful for Researchers can also use BIOTREE-NET to investigate ecological communities, analyse species turnover along environmental gradients, and assist in identifying comparable forest ecosystems by matching information amongst research sites. Because BIOTREE-NET incorporates plots of different sizes, such research implies the use of methods that enable comparison of samples of unequal size. We are at present working on the development of rarefaction methods for this purpose (L. Cayuela et al., unpublished results). Taxonomic uncertainty can be also incorporated to the analyses of ecological communities by randomly re-assigning non identified species in each

site to any of the other species found in the remaining sites in an iterative fashion. This allows estimation of a range of plausible values for the parameter of interest under different scenarios of re-assigned species identities (Cayuela et al. 2011).

A set of tools that provides a database with the ability to run spatial queries will be incorporated into the database through the use of PostGIS. The results of queries will be fed directly into the open source statistical language $\mathrm{R}$ within which spatial models can be built and evaluated. Implemented models will include GAMs, tree-based models (CART), generalized linear models and maximum entropy models. Scripts will be implemented on the server and results presented to users in the form of maps and graphical outputs based on submitted queries. The $\mathrm{R}$ language will also be incorporated within the PostgreSQL database using the PL/R package. Dynamic overlays will be possible online through spatial queries that allow data to be combined in various ways to address complex research questions. Visualisation of the results of online queries will be provided in the form of web pages and downloadable data files. This output will help resolve specific data needs.

Because a major goal of the project is to provide a powerful and flexible framework that will meet a variety of research needs, researchers with knowledge of SQL will be permitted and encouraged to build and submit their own spatial queries to the system in order to address specific questions. To that end, full documentation regarding the database scheme and structure will be provided for users with the appropriate privileges. The documentation will also include examples on the use of the modelling structure.

Table 2: The twenty most frequent species in the forest plots of the BIOTREE-NET database and the number of plots in which each species is present.

\begin{tabular}{lc}
\hline \multicolumn{1}{c}{ Species } & Number of plots \\
\hline Dendropanax arboreus (L.) Decne. \& Planch. & 354 \\
Quercus segoviensis Liebm. & 328 \\
Pinus oocarpa Schiede ex Schltdl. & 261 \\
Quercus crispipilis Trel. & 252 \\
Bursera simaruba (L.) Sarg. & 241 \\
Cordia alliodora (Ruiz \& Pav.) Oken & 238 \\
Brosimum alicastrum Sw. & 230 \\
Pinus maximinoi H.E. Moore & 222 \\
Cleyera theoides (Sw.) Choisy & 210 \\
Pinus tecunumanii F. Schwerdtf. ex Eguiluz \& J.P.Perry & 189 \\
Virola sebifera Aubl. & 178 \\
Quercus crassifolia Humb. \& Bonpl. & 176 \\
Lacistema aggregatum (Bergius) Rusby & 171 \\
Cecropia obtusifolia Bertol. & 171 \\
Persea americana Mill. & 165 \\
Simarouba amara Aubl. & 164 \\
Pinus pseudostrobus Lindl. & 161 \\
Cornus disciflora DC. & 161 \\
Guazuma ulmifolia Lam. & 160 \\
Cassipourea elliptica (Sw.) Poir. & 154 \\
\hline
\end{tabular}




\section{Contributing to the BIOTREE- NET project}

Anyone who wishes to contribute to the BIOTREE-NET project with forest inventory data is welcome to participate in this initiative. The BIOTREE-NET database is now publicly available (http://portal.biotreenet.com). The website contains clear instructions for how to get and use the data. Access to GIS layers will be however restricted to data contributors and project participants. It is important to note that contributors must sign an agreement to share and make their data public. This agreement guarantees free distribution of data as long as they are used for non-commercial purposes, and authorship is duly acknowledged whenever used. If data from BIOTREE-NET aim to be used in a scientific publication, data contributors must be given the opportunity to collaborate in such publication. Further information on the participation and data use agreement as well as on intellectual property rights can be found in the BIOTREE-NET website (http://www.biotreenet.com/english/html).

\section{Acknowledgements}

The original idea of the paper was conceived by L.C., D.J.G. and L.G.B. The technical specifications of the database were developed by R.P.P. In addition, F.S.A., R.A.Z., N.R.M., C.G., M.G.E., F.J.B., J.M.R.B. and R.Z. have contributed significantly to the development of the relational structure of the database, the definition of the taxonomic standardisation protocol, and the elaboration of the participation and data use agreement. This paper was written by L.C. with significant input from R.F., L.G.B., D.M.G., P.B., E.V., J.M.R.B., S.A.S., B.F.R., M.O.V., D.L.K., G.A.I., G.W.L., R.A.Z., C.G., and W.F.G. The data stored in BIOTREENET have been provided by L.C., D.J.G., N.R.M., M.G.E., P.B., S.W.B., A.C.C., M.A.C., I.C., B.J., R.C. I.C., J.F., R.F., B.F.R., W.F.G., L.G.J., T.W.G., B.G.R., J.E.G., D.M.G., J.H., G.A.I., D.L.K., J.L., S.G.L., S.M., J.A.M., E.V.M., V.M., S.O.G., M.O.V., C.J.P., V.R.G., K.A.S., S.A.S., F.T.D., E.V., K.M.V., D.A.W., J.N.W. and G.W.L. BIOTREE-NET development has been supported primarily by Fundación BBVA (project BIOCON08_044). We thank Gabriela LopezGonzalez and an anonymous reviewer for their comments and suggestions.

\section{References}

Arino, O., Bicheron, P., Achard, F., Latham, J., Witt, R. Weber, J.-L. (2008): GLOBCOVER: the most detailed portrait of the Earth. - ESA Bulletin 136: 24-31.

Bawa, K.S. (2004): Beyond paradise: Meeting the challenges in tropical biology in the $21^{\text {st }}$ century. - Biotropica 36 : 276-284. CrossRef

Bonan, G B. (2008): Forests and climate change: forcings, feedbacks, and the climate benefits of forests. - Science 320: 1444-1449. CrossRef

Boreaux, V., Born, J., Lawes, M.J. (2009): Sharing ecological knowledge: opportunities and barriers to uptake. Biotropica 41: 532-534.

Bradshaw, C.J.A., Sodhi, N.S., Brook, B.W. (2009): Tropical turmoil: a biodiversity tragedy in progress. - Frontiers in Ecology and the Environment 7: 7987. CrossRef

Brooks T., Hannah, L., da Fonseca, G.A.B., Mittermeier, R.A. (2001): Prioritizing hotspots, representing transitions. - Trends in Ecology and Evolution 16: 673-673. CrossRef

Brooks, T.M., Mittermeier, R.A., Mittermeier, C., Da Fonseca, G.A.B., Rylands, A.B., Konstant, W.R., Flick, P., Pilgrim, J., Oldfield, S., Magin, G., Hilton-Taylor, C. (2002): Habitat loss and extinction in the hotspots of biodiversity. - Conservation Biology 16: 909-923. CrossRef

Brotons, L., Thuiller, W., Araújo, M.B., Hirzel, A.H. (2004): Presence-absence versus presence-only modelling methods for predicting bird habitat suitability. Ecography 27: 437-448. CrossRef

Brown, J.H., Lomolino, M.V. (1998): Biogeography. 2nd ed. - Sunderland, Massachusetts: Sinauer Press.

Chazdon, R.L., Harvey, C.A., Komar, O., Griffith, D.M., Ferguson, B.G., MartinezRamos, M., Morales, H., Nigh, R., SotoPinto, L., van Breugel, M., Philpot, S.M. (2009): Beyond reserves: a research agend for conserving biodiversity in human-modified tropical landscapes. Biotropica 41: 142-153. CrossRef

Cayuela, L. (2012): Taxonstand: Taxonomic standardization of plant species names. - R package version 1.0. - URL: http://cran.r-

project.org $/$ package $=$ Taxonstand

Cayuela, L., de la Cruz, M., Ruokolainen, K. (2011): A method to incorporate the effect of taxonomic uncertainty on multivariate analyses of ecological data. Ecography 34: 94-102. CrossRef

Cayuela, L., Golicher, J.D., Newton, A.C., Kolb, M., Albuquerque, F.S., Arets, E.J.M.M., Alkemade, J.R.M., Pérez, A.M. (2009): Species distribution modelling in the tropics: problems, potentialities, and the role of biological data for effective species conservation. - Tropical Conservation Science 2: 319-352.
Cayuela, L., Pérez, R., Bonet, F.J., Ramírez-Marcial, N., Zahawi, Z., de Albuquerque, F.S., Garibaldi, C., Gálvez, L., Golicher, D.J., González-Espinosa, M., Rey Benayas, J.M., Zamora, R. (2010): Structure of BIOTREE-NET relational database and description on terms, version 1.0. - Granada, Spain: BIOTREE-NET: The Forest Inventory Plot Network. - URL: http://www.biotreenet.com/english/pdf/St ructure_BIOTREE-NET_database.pdf [accessed on 2010-12-27].

DeClerck, F.A.J., Chazdon, R., Holl, K.D., Milder, J.C., Finegan, B., MartinezSalinas, A., Imbach, P., Canet, L., Ramos, Z. (2010): Biodiversity conservation in human-modified landscapes of Mesoamerica: past, present and future. - Biological Conservation 143: 23012313. CrossRef

Dengler, J., Jansen, F., Glöckler, F., Peet, R.K., de Cáceres, M., Chytrý, M., Ewald, J., Oldeland, J., Lopez-Gonzalez, G., Finckh, M., Mucina, L., Rodwell, J.S., Schaminée, J.H. J., Spencer, N. (2011): The Global Index of Vegetation-Plot Databases (GIVD): a new resource for vegetation science. - Journal of Vegetation Science 22: 582-597. CrossRef

Dewalt, S.J., Schnitzer, S.A., Denslow, J.S. (2000): Density and diversity of Iianas along a chronosequence on a central Panamanian lowland forest. - Journal of Tropical Ecology 16: 1-19. CrossRef

Dinerstein, E., Powell, G., Olson, D.M., Wikramanayake, E., Abell, R., Loucks, C., Underwood, E., Allnutt, T., Wettengel, W., Ricketts, T., Strand, H., O'Connor, S., Burgess, N. (2000): A workbook for conducting biological assessments and developing biodiversity visions for ecoregion-based conservation. - Washington, D.C.: World Wildlife Fund.

Doraiswamy, P.C., Pasteris, P.A., Jones, K.C., Motha, R.P., Nejedlik, P. (2000): Techniques for methods of collection, database management and distribution of agrometeorological data. - Agricultural and Forest Meteorology 103: 8397. CrossRef

Erwin, T.L. (1982): Tropical forests: their richness in Coleoptera and other arthropod species. - The Coleopterists' Bulletin 36: 74-75.

Funk, S.M., Fa, J.E. (2010): Ecoregion prioritization suggests an armoury not a silver bullet for conservation planning. PloS One 5: e8923. CrossRef

Funk, V.A., Richardson, K.R., Ferrier, S. (2005): Survey-gap analysis in expeditionary research: where do we go from here? - Biological Journal of the Linnean Society 85: 549-567. CrossRef

Guisan, A., Graham, C.H., Elith, J., Huettmann, F., NCEAS Species Distribution Modeling Group. (2007): Sensitivity of predictive species distribution models to 
change in grain size. - Diversity and Distributions 13: 332-340. CrossRef

Hartshorn, G.S. (1983): Plants: introduction. - In: Janzen, D.H. [Ed.]: Costa Rican natural history: 118-157. Chicago, Illinois: University of Chicago.

Hijmans, R.J., Cameron, S.J., Parra, J.L. Jones, P.G., Jarvis, A. (2005): Very high resolution interpolated climate surfaces for global land areas. - International Journal of Climatology 25: 1965-1978. CrossRef

Hoffmann, M., Hilton-Taylor, C., Angulo, A., Böhm, M., Brooks, T.M., Butchart, S.H.M., Carpenter, K.E., Chanson, J., Collen, B., Cox, N.A., Darwall, W.R.T., Dulvy, N.K., Harrison, L.R., Katariya, V., Pollock, C.M., Quader, S., Richman, N.I., Rodrigues, A.S.L., Togenilli, M.F., Vié, J.-C., Aguiar, J.M., Allen, D.J., Allen, G.R., Amori, G., Ananjeva, N.B., Andreone, F., Andrew, P., Aquino Ortiz, A.L., Baillie, J.E.M., Baldi, R., Bell, B.D., Biju, S.D., Bird, J.P., Black-Decima, P., Blanc, J.J., Bolaños, F., Bolivar-G., W., Burfield, I.J., Burton, J.A., Capper, D.R., Castro, F., Catullo, G., Cavanagh, R.D., Channing, A., Chao, N.L., Chenery, A.M., Chiozza, F., Clausnitzer, V., Collar, N.J., Collett, L.C., Collette, B.B., Cortez Fernandez, C.F., Craig, M.T., Crosby, M.J., Cumberlidge, N., Cuttelod, A., Derocher, A.E., Diesmos, A.C., Donaldson, J.S., Duckworth, J.W., Dutson, G., Dutta, S.K., Emslie, R.H., Farjon, A., Fowler, S., Freyhof, J., Garshelis, D.L., Gerlach, J., Gower, D.J., Grant, T.D., Hammerson, G.A., Harris, R.B., Heaney, L.W., Hedges, S.B., Hero, J.-M., Hughes, B., Hussain, S.A., Icochea, J.M., Inger, R.F., Ishii, N., Iskandar, D.T., Jenkins, R.K.B., Kaneko, Y., Kottelat, M., Kovacs, K.M., Kuzmin, S.L., La Marca, E., Lamoreux, J.F., Lau, M.W.N., Lavilla, E.O., Leus, K., Lewison, R.L., Lichtenstein, G., Livingstone, S.R., Lukoschek, V., Mallon, D.P., McGown, P.J.K., Mclvor, A., Moehlman, P.D., Molur, S., Muñoz Alonso, A., Musick, J.A., Nowell, K., Nussbaum, R.A., Olech, W., Orlov, N.L., Papenfuss, T.J., Parra-Olea, G., Perrin, W.F., Polidoro, B.A., Pourkazemi, M., Racey, P.A., Ragle, J.S., Ram, M., Rathbun, G., Reynolds, R.P., Rhodin, A.G.J., Richards, S.J., Rodríguez, L.O., Ron, S.R., Rondinini, C., Rylands, A.B., Sadovy de Mitcheson, Y., Sanciangco, J.C., Sanders, K.L., Santos-Barrera, G., Schipper, J., SelfSullivan, C., Shi, Y., Schoemaker, A., Short, F.T., Sillero-Zubiri, C., Silvano, D.L., Smith, K.G., Smith, A.T., Snoeks, J., Stattersfield, A.J., Symes, A.J., Taber, A.B., Talukdar, B.K., Temple, H.J., Timmins, R., Tobias, J.A., Tsytsulina, K., Tweddle, D., Ubeda, C., Valenti, S.V., van Dijk, P.P., Veiga, L.M., Veloso, A., Wege, D.C., Wilkinson, M., Williamson, E.A., Xie, F., Young, B.E.,
Akçakaya, H.R., Bennun, L., Blackburn, T.M., Boitani, L., Dublin, H.T., da Fonseca, G.A.B., Gascon, C., Lacher Jr., T.E., Mace, G.M., Mainka, S.A., McNeely, J.A., Mittermeier, R.A., Reid, G.M., Rodriguez, J.P., Rosenberg, A.A., Samways, M.J., Smart, J., Stein, B.A., Stuart, S.N. (2010): The impact of conservation on the status of the world's vertebrates. - Science 330: 1503-1509. CrossRef

IUCN (2010): IUCN Red List of Threatened Species. Version 2010.4. - URL: http://www.iucnredlist.org [accessed on 2010-10-27]

Kissling, W.D., Field, R., Korntheuer, H., Heyder, U., Böhning-Gaese, K. (2010): Woody plants and the prediction of climate change impacts on bird diversity. Philosophical Transactions of the Royal Society B 365: 2035-2045. CrossRef

Laurance, W.F. (1999): Reflections on the tropical deforestation crisis. - Biological Conservation 91: 109-117. CrossRef

Laurance, W.F. (2007): Have we overstated the tropical biodiversity crisis? Trends in Ecology and Evolution 22: 6570. CrossRef

Leff, A., Rayfield, J.T. (2001): Webapplication development using the model/view/controller design pattern. 01 Proceeding of the Fifth IEEE International Enterprise Distributed Object Computing Conference: 118-118. Washington, DC: IEEE Computer Society.

Lomolino, M.V. (2004): Conservation biogeography. - In: Lomolino, M.V., Heaney, L.R. [Eds.]: Frontiers of biogeography: new directions in the geography of nature: 293-296. Sunderland, Massachusetts: Sinauer Associates.

Lopez-Gonzalez, G., Burkitt, M., Lewis, S.L., Phillips, O.L. (2012): ForestPlots.net - managing permanent plot information across the tropics. - In: Dengler, J., Oldeland, J., Jansen, F., Chytrý, M., Ewald, J., Finckh, M., Glöckler, F., Lopez-Gonzalez, G., Peet, R.K., Schaminée, J.H.J. (2012) [Eds.]: Vegetation databases for the 21st century. Biodiversity \& Ecology 4: 95-103. Hamburg: Biocentre Klein Flottbek and Botanical Garden. CrossRef

Lughadha, E.N., Baillie, J., Barthlott, W., Brummitt, N.A., Cheek, M.R., Farjon, A., Govaerts, R., Hardwick, K.A., HiltonTaylor, C., Meagher, T.R., Moat, J., Mutke, J., Paton, A.J., Pleasants, L.J., Savolainen, V., Schatz, G.E., Smith, P., Turner, I., Wyse-Jackson, P., Crane, P.R. (2005): Measuring the fate of plant diversity: towards a foundation for future monitoring and opportunities for urgent action. - Philosophical Transactions of the Royal Society B 360: 359-372.

Malhi, Y., Phillips, O.L., Lloyd, J., Baker, T.R., Wright, J., Almeida, S., Arroyo, L., Frederiksen, T., Grace, J., Higuchi, N., Killeen, T., Laurance, W.F., Leaño, C.,
Lewis, S., Meir, P., Monteagudo, A. Neill, D., Núñez Vargas, P., Panfil, S. Patiño, S., Pitman, N., Quesada, C.A., Rudas-LI. A., Salomão, R., Saleska, S. Silva, N., Silveira, M., Sombroek, W.G. Valencia, R., Vásquez Martínez, R. Vieira, I.C.G., Vinceti, B. (2002): An international network to monitor the structure, composition and dynamics of Amazonian forests (RAINFOR). - Journal of Vegetation Science 13: 439-450. CrossRef

Myers, N., Mittermeier, R.A., Mittermeier, C.G., da Fonseca, G.B., Kent, J. (2000): Biodiversity hotspots for conservation priorities. - Nature 403: 853-858 CrossRef

Novotny, V., Drozd, P., Miller, S.E., Kulfan, M., Janda, M., Basset, Y., Weiblen, G.D. (2006): Why are there so many species of herbivorous insects in tropical rainforests? - Science 313: 1115-1118. CrossRef

Olson, D.M., Dinerstein, E. (2002): The Global 200: priority ecoregions for global conservation. - Annals of the Missouri Botanical Garden 89: 199-224. CrossRef

Pereira, H.M., Cooper, H.D. (2006): Towards the global monitoring of biodiversity change. - Trends in Ecology and Evolution 21:123-129. CrossRef

Pereira, H.M., Leadley, P.W., Proença, V., Alkemade, R., Scharlemann, J.P.W., Fernandez-Manjarrés, J.F., Araújo, M.B., Balvanera, P., Biggs, R., Cheung, W.W.L., Chini, L., Cooper, H.D., Gilman, E. L., Guénette, S., Hurtt, G.C., Huntington, H.P., Mace, G.M., Oberdorff, T. Revenga, C., Rodrigues, P., Scholes, R.J., Sumaila, U.R., Walpole, M. (2010): Scenarios for global biodiversity in the 21st century. - Science 330: 14961501. CrossRef

Ponette-Gonzalez, A.G., Weathers, K.C., Curran, L.M. (2010): Water inputs across a tropical montane landscape in Veracruz, Mexico: synergistic effects of land cover, rain and frog seasonality, and interannual precipitation variability. - Global Change Biology 16: 946-963.

Prendergast J.R., Quinn, R.M., Lawton, J.H. (1999): The gaps between theory and practice in selecting nature reserves. - Conservation Biology 13: 484 492. CrossRef

R Development Core Team (2011): R: A language and environment for statistical computing. - Vienna: R Foundation for Statistical Computing. URL: http://www.R-project.org/.

Scholes, R.J., Mace, G.M., Turner, W., Geller, G.N., Jürgens, N., Larigauderie, A., Muchoney, D., Walther, B.A., Mooney, H.A. (2009): Toward a Global Biodiversity Observing System. - Science 321:1044-1045. CrossRef

Shanley, P., Lopez. C. (2009): Out of the loop: Why research rarely reaches policy makers and the public and what can be 
done. - Biotropica 41: 535-544. CrossRef

Sodhi, N.S., Koh, L.P., Brook, B.W., Ng, P.K.L. (2004): Southeast Asia biodiversity: An impending disaster. - Trends in Ecology and Evolution 19: 654-659. CrossRef

Sporn, S.G., Bos, M.M., Kessler, M. (2010): Vertical distribution of epiphytic briophytes in an Indonesian rainforest. Biodiversity and Conservation 19: 745760. CrossRef

Stork, N.E. (2010): Re-assessing current extinction rates. - Biodiversity and Conservation 19: 357-371. CrossRef

Ter Steege, H., Pitman, N., Phillips, O.L., Chave, J., Sabatier, D., Duque, A., Molino, J.F., Prevost, M.F., Spichiger, R., Castellanos, H., van Hildebrand, P., Vasquez, R. (2006): Continental-scale patterns of canopy tree composition and function across Amazonia. - Nature 443: 444-447. CrossRef

Ruby, S., Thomas, D., Hansson, D.H. (2009): Agile web development with Rails. 3rd ed. - Raleigh, North Carolina, USA: The Pragmatic Bookshelf.

United Nations. (1992): The Convention on Biological Diversity. - United Nations. URL: http://www.cbd.int/convention/text/ [accessed on 2010-12-28].

WDPA. (2010): World Database on Protected Areas (WDPA) Consortium 2009. World database on protected areas. Washington, DC: IUCN, WDPA and UNEP (United Nations Environment Programme), WCMC (World Conservation Monitoring Centre). URL:http://sea.unepwcmc.org/wdbpa/index.htm [accessed on 2010-09-03].

White, D.A., Hood, C.S. (2004): Vegetation patterns and environmental gradients in tropical dry forests of the northern Yuca$\tan$ Peninsula. - Journal of Vegetation Science 15: 151-160. CrossRef

Whittaker, R.J., Araújo, M.B., Jepson, P., Ladle, R.J., Watson, J.E.M., Willis, K.J. (2005): Conservation biogeography: assessment and prospect. - Diversity and Distributions 11: 3-23. CrossRef

Wright, S.J., Muller-Landau, H.C. (2006): The future of tropical forest species. Biotropica 38: 287-301. CrossRef

WWF [World Wildlife Fund] (2010): Terrestrial ecoregions of the world. - World Wildlife Fund. URL: http://www. worldwildlife.org/science/data litem1872.html [accessed on 2010-0920].

Yesson C., Brewer, P.W., Sutton, T., Caithness, N., Pahwa, J.S., Burgess, M., Gray, W.A., White, R.J., Jones, A.C., Bisby, F.A., Culham, A. (2007): How global is the Global Biodiversity Information Facility? - PLoS One 2: e1124. CrossRef

Zhao, Z.W., Wang, G.H., Yang, L. (2003): Biodiversity of arbuscular mycorrhizal fungi in a tropical rainforest of
Xishuangbanna, southwest China. Fungal Diversity 13: 233-242.

Luis Cayuela* (luis.cayuela@urjc.es) Area de Biodiversidad y Conservación Universidad Rey Juan Carlos

c/ Tulipán s/n

28933 Móstoles, Madrid, SPAIN

Lucía Gálvez-Bravo

(lucia.galvez@uclm.es)

Instituto de Investigación en Recursos

Cinegéticos (IREC-CSIC-UCLM-JCCM)

Ronda de Toledo s/n

13071 Ciudad Real, SPAIN

\section{Ramón Pérez Pérez}

(ramon.pperez@gmail.com), Fábio S. De Albuquerque (fsuzart@ugr.es), Francisco J. Bonet (fjbonet@gmail.com) \& Regino

Zamora (rzamora@ugr.es)

Departamento de Ecología

Centro Andaluz de Medio Ambiente,

Universidad de Granada, Junta de

Andalucía

Avda. del Mediterráneo s/n

18006 Granada, SPAIN

Duncan J. Golicher

(dgolicher@gmail.com)

School of Conservation Science,

Bournemouth University

Talbot Campus, Poole

Dorset BH12 5BB, UNITED KINGDOM

Rakan A. Zahawi (zahawi@ots.ac.cr)

Las Cruces Biological Station \& Wilson

Botanical Garden, Organization for

Tropical Studies

Apdo 73-8257

San Vito de Coto Brus, COSTA RICA

Neptalí Ramírez-Marcial

(nramirezm@ecosur.mx), Mario

González-Espinosa

(mgonzale@ecosur.mx) \& Miguel Angel

Castillo (mcastill@ecosur.mx)

El Colegio de la Frontera Sur, Unidad San

Cristóbal

Carretera Panamericana y Periférico Sur

s/n, San Cristóbal de las Casas

CP 29290, Chiapas, MEXICO

Cristina Garibaldi

(crisgaribaldi@yahoo.com)

Departamento de Botánica, Universidad

de Panamá

Panama City, PANAMA
Richard Field

(richard.field@nottingham.ac.uk)

School of Geography, University of

Nottingham

University Park

Nottingham NG7 2RD, UNITED

KINGDOM

José M. Rey Benayas (josem.rey@uah.es) Departamento de Ecología, Universidad de Alcalá

Crta. De Barcelona km. 33,600

28871 Alcalá de Henares, SPAIN

Patricia Balvanera

(pbalvane@oikos.unam.mx)

Centro de Investigaciones en

Ecosistemas, Universidad Nacional

Autónoma de México

Apdo. Post. 27-3, Xangari

CP 58089, Morelia, Michoacán, MEXICO

Blanca L. Figueroa-Rangel

(bfrangel@cucsur.udg.mx) \& Miguel

Olvera-Vargas (molvera@ cucsur.udg.mx)

Departamento de Ecología y Recursos

Naturales, Universidad de Guadalajara

Apartado Postal 108

CP 48900, Autlán de la Grana, Jalisco, MEXICO

Daniel M. Griffith

(griffith08@gmail.com)

Biodiversity of Bosawas Project

(Nicaragua), Saint Louis Zoo

St. Louis, Missouri, UNITED STATES

Gerald A. Islebe (gislebe@ecosur.mx) \&

Mirna Valdez-Hernández

(mavaldez@ecosur.mx)

El Colegio de la Frontera Sur, Unidad

Chetumal, Herbario

Avenida Centenario Km 5.5

Chetumal, Quintana Roo, MEXICO

Daniel L. Kelly (rdelcast@yahoo.com) Department of Botany, School of Natural Sciences, Trinity College,

University of Dublin

Dublin 2, IRELAND

Stefan A. Schnitzer (schnitze@uwm.edu)

Scott A. Mangan

(smangan37@gmail.com)

Department of Biological Sciences,

University of Wisconsin

PO Box 413

Milwaukee, WI 53201, UNITED STATES 
Eduardo Velázquez

(eduardo.velazquez@ufz.de)

Department of Ecological Modelling,

Helmholtz Centre for Environmental

Research - UFZ

Permoserstraße 15

04318 Leipzig, GERMANY

Guadalupe Williams-Linera

(Guadalupe.williams@inecol.edu.mx)

Red de Ecología Funcional

Instituto de Ecología A.C.

Carretera Antigua a Coatepec. 351

Xalapa, Veracruz, CP 91070, MEXICO

Steven W. Brewer

(scruffy23@gmail.com)

Belize Foundation for Research \&

Environmental Education

PO Box 129

Punta Gorda, BELIZE

Angélica Camacho-Cruz

(acamacho@biocores.org.mx) \& Luis

Galindo-Jaimes (jlinares@zamorano.edu)

Biodiversidad: Conservación y

Restauratión, A.C.

Tapachula \# 17, El Cerrillo

San Cristóbal de Las Casas

CP 29220, Chiapas, MEXICO

Indiana Coronado

(Indiana.Coronado@mobot.org)

Missouri Botanical Garden

PO Box 299

St. Louis, MO 63166-0299, UNITED

STATES

Ben de Jong (bjong@ecosur.mx) \&

Susana Ochoa-Gaona

(sochoa@ecosur.mx)

El Colegio de la Frontera Sur, Unidad

Villahermosa

Apartado Postal 1042

Villahermosa, Tabasco

CP 86100, MEXICO

Rafael del Castillo (rdelcast@yahoo.com)

CIIDIR Oaxaca, IPN

Hornos 1003

CP 71230, Xoxocotlán, Oaxaca,

MEXICO

Ínigo Granzow-de la Cerda

(inyigo.delacerda@uab.cat)

University Herbarium and Dept. of

Ecology and Evolutionary Biology,

University of Michigan

3600 Varsity Dr.

Ann Arbor, MI 48108-2228, UNITED

STATES
Javier Fernández

(javfernandezvega@gmail.com)

School of Forestry and Environmental

Studies, Yale University

205 Prospect Street

New Haven, CT 06511, UNITED

STATES

William Fonseca (wfonseca@una.ac.cr)

Escuela de Ciencias Ambientales

Universidad Nacional de Costa Rica

Apdo. 86-3000

Heredia, COSTA RICA

Thomas W. Gillespie (tg@geog.ucla.edu)

Department of Geography

1255 Bunche Hall

Los Angeles, CA 90095-1524, UNITED STATES

Benigno González-Rivas

(benigno@una.edu.ni)

Departamento de Manejo de Bosques y

Ecosistemas, Universidad Nacional

Agraria

Managua, NICARAGUA

James E. Gordon

(James.GORDON@iucn.org)

Knowledge Management Officer, Forest

Conservation Programme, IUCN

Rue Mauverney 28

1196 Gland, SWITZERLAND

Johanna Hurtado

(jhurtado@sloth.ots.ac.cr)

Organization for Tropical Studies

Apartado 676-2050

San Pedro, COSTA RICA

José Linares (jlinares@zamorano.edu)

Herbario Paul C. Standley, Escuela

Agrícola Panamericana Zamorano

PO Box 93

Tegucigalpa, HONDURAS

Susan G. Letcher

(susan_letcher@hotmail.com)

Organization for Tropical Studies

Apartado Postal 676-2050

11501 San Pedro de Montes de Oca,

COSTA RICA

Jorge A. Meave

(jorge.meave@ciencias.unam.mx)

Departamento de Ecología y Recursos

Naturales

Universidad Nacional Autónoma de

México

Mexico Distrito Federal CP 04510, MEXICO
Ernesto V. Méndez (emendez@uvm.edu) Department of Plant \& Soil Science,

University of Vermont

153 South Prospect Street

Burlington, Vermont 05401, UNITED

STATES

\section{Victor Meza}

(vmezap@una.ac.cr)

Instituto de Investigación y Servicios

Forestales

Universidad Nacional de Costa Rica.

Campus Omar Dengo

Apdo. 86-3000

Heredia, COSTA RICA

Chris J. Peterson

(chris@plantbio.uga.edu)

Department of Plant Biology, University

of Georgia

2502 Plant Science Building

Athens, GA 30602, UNITED STATES

Viviana Ruiz-Gutierrez

(vr45@ cornell.edu)

Neotropical Conservation Initiative,

Cornell Lab of Ornithology

159 Sapsucker Woods Road

Ithaca, NY 14850, UNITED STATES

Kymberley A. Snarr

(kym.snarr@utoronto.ca)

Centre for Environment

University of Toronto

33 Willcocks Street

Toronto, Ontario M5S 3E8, CANADA

Fernando Tun Dzul (fjtun@ cicy.mx)

Unidad de Recursos Naturales, entro de Investigación Científica de Yucatán C-43 \# 130 Col. Chuburná de Hidalgo CP 97200, Mérida, Yucatán MEXICO

Karin M. Viergever

(karin.viergever@ecometrica.co.uk)

Ecometrica,

Top Floor, Unit 3B Kittle Yards

Edinburgh, EH9 1PJ, UNITED

KINGDOM

David A. White (dawhite@loyno.edu) Department of Biological Sciences, Loyola University

New Orleans, LA 70118, UNITED STATES

John N.Williams (jnwill@ucdavis.edu) Department of Environmental Science and Policy, University of California

One Shields Avenue

Davis, CA 95616, UNITED STATES 